\title{
Quantification of copepod gut content by differential length amplification quantitative PCR (dla-qPCR)
}

\author{
Christofer Troedsson · Paolo Simonelli • \\ Verena Nägele $\cdot$ Jens $C$. Nejstgaard · \\ Marc E. Frischer
}

Received: 26 March 2008/Accepted: 20 October 2008/Published online: 8 November 2008

(C) The Author(s) 2008. This article is published with open access at Springerlink.com

\begin{abstract}
Quantification of feeding rates and selectivity of zooplankton is vital for understanding the mechanisms structuring marine ecosystems. However, methodological limitations have made many of these studies difficult. Recently, molecular based methods have demonstrated that DNA from prey species can be used to identify zooplankton gut contents, and further, quantitative gut content estimates by quantitative PCR (qPCR) assays targeted to the 18S rRNA gene have been used to estimate feeding rates in appendicularians and copepods. However, while standard single primer based qPCR assays were quantitative for the filter feeding appendicularian Oikopleura dioica, feeding rates were consistently underestimated in the copepod Calanus finmarchicus. In this study, we test the hypothesis that prey DNA is rapidly digested after ingestion by copepods and describe a qPCR-based assay, differential length amplification qPCR (dla-qPCR), to account for DNA digestion. The assay utilizes multiple primer sets that amplify different sized fragments of the prey 18S rRNA gene and, based on the differential amplification of these fragments, the degree of digestion is estimated and corrected for. Application of this approach
\end{abstract}

Communicated by A. Atkinson.

C. Troedsson $(\varangle) \cdot$ P. Simonelli

Department of Biology, University of Bergen,

P.O. Box 7800, 5020 Bergen, Norway

e-mail: christofer.troedsson@bio.uib.no

C. Troedsson · V. Nägele · M. E. Frischer

Skidaway Institute of Oceanography,

10 Ocean Science Circle, 31411 Savannah, Georgia

J. C. Nejstgaard

Department of Biology, UNIFOB,

P.O. Box 7800, 5020 Bergen, Norway to C. finmarchicus fed Rhodomonas marina significantly improved quantitative feeding estimates compared to standard qPCR. The development of dla-qPCR represents a significant advancement towards a quantitative method for assessing in situ copepod feeding rates without involving cultivation-based manipulation.

\section{Introduction}

Mesozooplankton, in particular copepods, dominate the marine plankton biomass and play a critical role in the marine food web as selective predators, selective nutrient regenerators, carbon export regulators, and mediators of energy to higher trophic levels (Verity and Smetacek 1996). Thus, the ability to accurately estimate copepod feeding preferences and rates is vital for a quantitative understanding of trophic interactions and processes that structure marine ecosystems. However, because of methodological constraints, it remains a challenge to identify and quantify copepod feeding in situ without significant experimental bias (Båmstedt et al. 2000; Nejstgaard et al. 2003; Nejstgaard et al. 2008).

In view of these challenges, new methodologies using prey-specific DNA as biomarkers for the study of trophic interactions has yielded promising results (Sheppard and Harwood 2005). For example, genetic techniques based on PCR amplification have been successfully applied in qualitative dietary studies of carnivorous insects and other organisms (Symondson 2002; Harper et al. 2005; Harwood and Obrycki 2005; Sheppard and Harwood 2005) including marine vertebrates (Jarman et al. 2002) and invertebrates (Blankenship and Yayanos 2005). Recently, our group developed a PCR based assay for detection of prey content 
in the gut of the calanoid copepod Calanus finmarchicus (Nejstgaard et al. 2003). These studies demonstrated successful extraction and PCR amplification of the prey algal 18S ribosomal DNA from the gut of calanoid copepods and in their fecal pellets. Although these results were based on conventional end-point PCR, they suggested that it should be possible to quantify gut content by PCR and therefore estimate feeding rates if gut resident times are known.

Based on this hypothesis, a real time quantitative PCR (qPCR) assay was developed to determine zooplankton prey ingestion rates (Troedsson et al. 2007; Nejstgaard et al. 2008). When applied to the appendicularian Oikopleura dioica, realistic quantitative feeding and house trapping rates were observed (Troedsson et al. 2007). However, when a similar assay was applied to copepods, prey ingestion rates were significantly underestimated compared to independent methods (Nejstgaard et al. 2008). A possible explanation for the underestimation of ingested prey cells by qPCR is the digestion of prey genomic DNA in copepod gut. This hypothesis is supported by previous reports of prey genomic DNA degradation in predator guts and feces (Zaidi et al. 1999; Hoogendoorn and Heimpel 2001; Symondson 2002; Jarman et al. 2004; Sheppard and Harwood 2005; Deagle et al. 2006). In particular, Deagle et al. (2006) used qPCR to assess prey and predator DNA quality in feces. They measured the amount of DNA damage associated with food items in the feces of sea lions (Eumetopias jubatus) by quantifying the recovery of different sized PCR amplicons.

Here we developed a similar approach to investigate and describe specific prey DNA degradation in copepod guts. We refer to this method as "differential length amplification quantitative polymerase chain reaction" (dla-qPCR), and by amplifying different sized fragments of the same prey target gene extracted from copepod guts, we hypothesize that it would be possible to generate a digestion profile of a target prey species consumed by a copepod. These digestion profiles could then be used to correct for loss due to digestion and applied to extrapolate absolute estimates of prey cell number in the copepod gut.

\section{Material and methods}

\section{Algal prey}

In this study, we used the cryptophyte Rhodomonas marina (Dangeard) Lemmermann as prey for the calanoid copepod Calanus finmarchicus (Gunnerus). R. marina was obtained from IFREMER, Brest, France. The alga was cultured in semi continuous batches in $f / 2$ media diluted 10 times (f/20) (Guillard 1975). Algal cultures were grown with a
14:10 light:dark photoperiod. The alga used in the experiments was always harvested during exponential growth.

Differential length amplification quantitative polymerase chain reaction (dla-qPCR)

Theoretically, since DNA cannot be digested to a fragment shorter than 1 base pair (bp), estimating the amount of gene targets from a $1 \mathrm{bp}$ product would provide a measure of the total number of target molecules prior to digestion (Fig. 1). From the experimental perspective, we therefore hypothesized that quantification of a short DNA fragment would yield a higher estimate than longer fragment. Based on this premise, we developed several qPCR primer sets that amplify different sized fragments of the same target gene. A regression line between amplicon size and estimated gene target number was then fitted to data which generates DNA digestion profiles (dla profiles). These profiles were then used to extrapolate target gene copy number at $1 \mathrm{bp}$ as a proxy for pre-digested prey DNA.

\section{Primers}

To obtain primary sequence of target genes in the qPCR assays, the near full length SSU rRNA gene originating from $R$. marina was amplified using universal 18S rDNA targeted primers and cloned into the bacterial plasmid vector $\mathrm{pCR}^{\circledR} 4$-TOPO (Invitrogen) as previously described

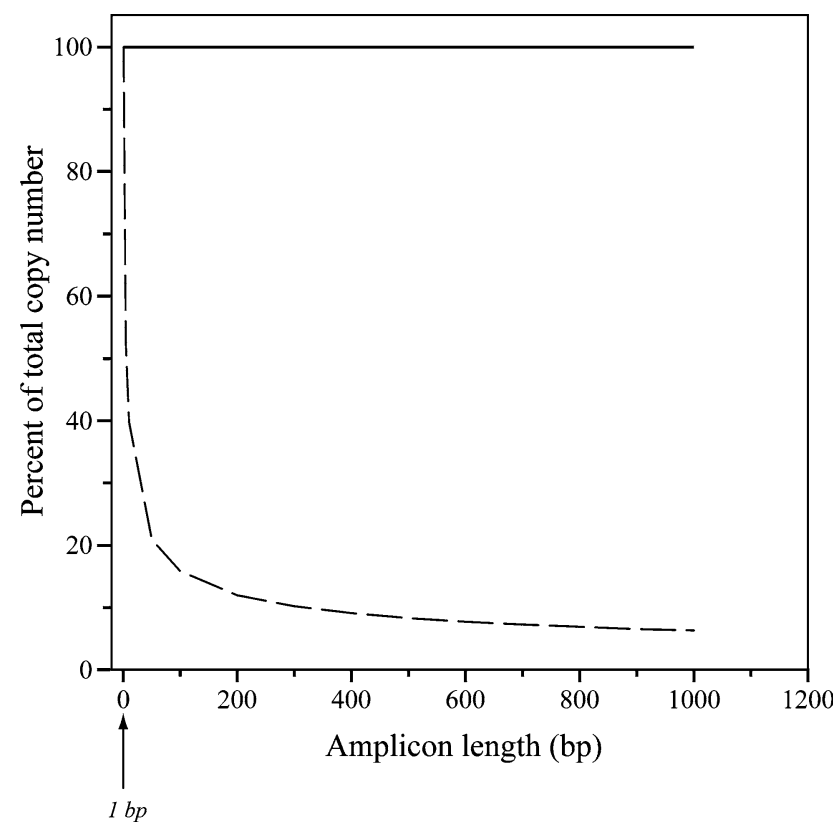

Fig. 1 Theoretical basis for dla-qPCR. Hypothesized relationship between quantitative amplification of different sized PCR amplicons in the presence (dotted line) and absence (continuous line) of nuclease activity. Gene copy number is estimated by extrapolation of the digestion profile to $1 \mathrm{bp}$ 
(Gruebl et al. 2002). The universal primers Univ F-15 (5' ctg cca gta gtc ata tgc $\left.3^{\prime}\right)$ and Univ R-1765S ( $5^{\prime}$ acc ttg tta cga ctt $3^{\prime}$ ) were used. Genomic DNA from algal cultures was purified using Qiagen's DNeasy ${ }^{\circledR}$ Blood \& Tissue kit (Qiagen, Inc.) as recommended by the manufacturer. Plasmid DNA was purified from the $\mathrm{pCR}^{\circledR} 4$-TOPO vector using the High Pure Plasmid Isolation Kit (Roche) following manufacturer's instructions. For sequencing, plasmids were purified using the High Pure plasmid isolation kit (Roche) and sequenced by capillary electrophoresis using the CEQ ${ }^{\mathrm{TM}}$ DTCS Quick start sequencing kit using a $\mathrm{CEQ}^{\mathrm{TM}} 8000$ 8-channel capillary sequencer (Beckmann Coulter, Inc.). The identities of fragments were confirmed by comparison to sequences in GenBank using the BLASTn utility (http://www.ncbi.nlm.nih.gov).

Six 18S rDNA targeted PCR primers were designed and utilized in this study. Sequences for each of these primers are shown in Table 1. All primer pairs, annealing conditions, expected amplicon size, qPCR primer efficiencies, and correlation coefficients between qPCR cycle $(\mathrm{Ct})$ and cell number are shown in Table 2. Rhodomonas sp. specific primers amplified fragments of increasing size from 74 to $616 \mathrm{bp}$ (74, 142, 213 and $616 \mathrm{bp})$. Initially primers were designed to include amplicons that were 1,000 bp long. However, the digestion of the Rhodomonas sp. genomic DNA was too extensive for detection of these amplicons and they were subsequently excluded from the analysis (data not shown). Primers were designed using the primer design tool GeneTool-lite v. 1.0 (BioTools, Inc.). Primers were empirically optimized for qPCR using a Bio-Rad iCyclerIQ Real-Time Detection System (Bio-Rad Laboratories, Inc.) and a MJResearch Opticon ${ }^{\circledR} 2$ real-time thermal cycler. All the primers designed in this study were optimized for these specific laboratory experiments, e.g. to not amplify Calanus sp. and not specifically designed to exclude amplification of other target species not included in our analysis. Therefore, these primers should be carefully tested before application in other experimental systems.

Table 1 Primers used in this study

\begin{tabular}{|c|c|}
\hline Primer $^{\mathrm{a}}$ & Primer sequence $\left(5^{\prime} \text { to } 3^{\prime}\right)^{\mathrm{b}}$ \\
\hline Rhod 97F & CGT TTA TTT GAT GGT CCC TTA \\
\hline Rhod 150R & GTC GGA CCT TTG TGC ATG TAT \\
\hline Rhod $1520 \mathrm{~F}$ & TCG TGA TGG GGA TAG ATT A \\
\hline Rhod 1030F & GCG ACT CCA TTG GCA CCT TGT \\
\hline Rhod $1450 \mathrm{~F}$ & GCG CGC TAC ACT GAT GAA TGC \\
\hline Rhod 1662R & TTT CAC CGG ACC ATT CAA TCG \\
\hline
\end{tabular}

\section{Controlled digestion of prey genomic DNA}

To understand the behavior of the dla-qPCR assay as target genes were increasingly digested under control conditions, initial experiments were conduced in which naked genomic DNA was subjected to digestion by DNase I (Ambion) for increasing amounts of time and then the amount of recovered target was estimated by dla-qPCR. Genomic DNA from $R$. marina was extracted using the Qiagen's DNeasy ${ }^{\circledR}$ Blood $\&$ Tissue extraction kit (Qiagen, Inc.). $20 \mathrm{ng}$ of genomic DNA were used for each experiment. DNase I was added at $1 / 50 \mathrm{U}$, corresponding to total digestion of $20 \mathrm{ng}$ genomic DNA in $10 \mathrm{~min}$ at $37^{\circ} \mathrm{C}$ (according to manufacturers instructions). DNase I was added and incubated for $30 \mathrm{~s}$, $1 \mathrm{~min}, 2 \mathrm{~min}$ and $10 \mathrm{~min}$ at $37^{\circ} \mathrm{C}$, and the reactions were ended by the addition of stop solution and further incubated $10 \mathrm{~min}$ at $70^{\circ} \mathrm{C}$. The samples were centrifuged $(20,000 \mathrm{~g}$, $2 \mathrm{~min}$ ) and the supernatant containing the digested $R$. marina genomic DNA was used for further analysis. All qPCR reactions in this experiment where preformed using the BioRad iCyclerIQ Real-Time Detection System (Bio-Rad Laboratories, Inc.). Genomic extractions from 10, 1, 0.1 and $0.01 \mathrm{ml}$ of algal cultures with known concentrations were used as standards (see correlation coefficients of standard curve in Table 2). All standards were run in triplicate.

\section{Gut content analysis}

To determine whether the dla-qPCR assay could be used to estimate pre-digested copepod gut content, controlled gut filling experiments using $C$. finmarchicus feeding on R. marina. (800-1,600 $\mu \mathrm{g} \mathrm{C}^{-1}$ ) was performed. These experiments were conducted following procedures described previously by Nejstgaard et al. (2003). Copepods were collected by gentle net tows from 0 to $30 \mathrm{~m}$ depth in the Raunefjord, western Norway $\left(60^{\circ} 16^{\prime} \mathrm{N}, 05^{\circ} 14^{\prime} \mathrm{E}\right)$ using a $500 \mu \mathrm{m}$ mesh size, $1 \mathrm{~m}$ diameter net with a 141 non filtering cod-end. The samples were diluted with 401 surface water and transferred within $30 \mathrm{~min}$ of collection to a walk-in cold room at in situ temperature $\left(5-10^{\circ} \mathrm{C}\right)$. Animals were maintained at constant temperature under dim light with a 14:10 h light:dark cycle. Stage CV or CVI females of $C$. finmarchicus were sorted into five litre beakers using a wide mouth pipette and acclimated to the experimental food concentrations of $R$. marina (800$1,600 \mu \mathrm{g} \mathrm{C}^{-1}$ ) for 4-6 days before use. At these food concentrations $C$. finmarchicus late copepodites have been documented to reach saturated feeding rates (Båmstedt et al. 1999). After food acclimatization, animals were starved for $3 \mathrm{~h}$ in filtered $(0.22 \mu \mathrm{m})$ seawater to allow complete gut evacuation prior to gut filling experiments. After starvation, animals were randomly split into five groups of ca. 35 individuals, transferred into new saturating 
Table 2 Product length and optimal annealing temperatures used in this study

\begin{tabular}{llllll}
\hline $\begin{array}{l}\text { Forward } \\
\text { primer }\end{array}$ & $\begin{array}{l}\text { Reverse } \\
\text { primer }\end{array}$ & $\begin{array}{l}\text { Product } \\
\text { length }\end{array}$ & $\begin{array}{l}\text { Annealing } \\
\text { temperature }\left({ }^{\circ} \mathrm{C}\right)\end{array}$ & $\begin{array}{l}\text { PCR } \\
\text { efficiency }\end{array}$ & $\begin{array}{l}\text { Correlation } \\
\text { efficiency }\end{array}$ \\
\hline Rhod 97F & Rhod 150R & 74 & 57.3 & 78.5 & 0.985 \\
Rhod 1520F & Rhod 1662R & 142 & 57.0 & 77.4 & 0.996 \\
Rhod 1450F & Rhod 1662R & 213 & 63.0 & 81.0 & 0.991 \\
Rhod 1030F & Rhod 1662R & 616 & 60.0 & 78.9 & 0.958 \\
\hline
\end{tabular}

suspensions of the same prey type in $450 \mathrm{ml}$ Perspex chambers with $500 \mu \mathrm{m}$ false bottoms, and incubated for 5 , 10, 20, and $30 \mathrm{~min}$. An initial sample (0 min) was collected as a starved control. After the incubation, copepods were removed and quickly rinsed by dipping the Perspex chambers in 4 consecutive baths of $450 \mathrm{ml}$ filtered $(0.22 \mu \mathrm{m})$ seawater and flash frozen in liquid nitrogen within 10-20 s to stop gut activity and prevent defecation before sampling. Within a few minutes, the copepods were thawed in filtered $(0.22 \mu \mathrm{m})$ seawater, collected onto a Petri-dish and randomly sorted under dim light into $1.5 \mathrm{ml}$ Eppendorf ${ }^{\mathrm{TM}}$ microtubes for DNA analysis, or glass tubes for gut pigment analysis (five individuals for each analysis and incubation). To minimize the risk of including prey algae from the water, copepods were sorted by grabbing the base of the antennule with a forceps and dip-washing each copepod in droplets of prey-free filtered seawater before transfer to the tubes. Care was taken to minimize the amount of water in the tubes, and to immediately re-freeze the sorted copepods in liquid nitrogen. Samples were then stored at $-80^{\circ} \mathrm{C}$ until analysis.

Copepods for gut pigment analyses were extracted for $12 \mathrm{~h}$ in $90 \%$ acetone at $4{ }^{\circ} \mathrm{C}$ and analyzed on a Turner Designs $^{\mathrm{TM}}$ Model 10-AU Fluorometer as previously described (Nejstgaard et al. 1995). Copepod gut pigment (chlorophyll $a$ and derivates) concentrations were calculated as described in Båmstedt et al. (2000).

Copepod and algal DNA was extracted using the DNeasy ${ }^{\circledR}$ Blood \& Tissue kit (Qiagen, Inc.) protocol as described by the manufacture's instructions for total DNA from animal tissues with an RNase A treatment as recommended by the manufacturer. All real time PCR reactions were performed in $25 \mu \mathrm{l}$ reaction volumes using the alga-specific primer sets (Table 2). All qPCR reactions in this set of experiments were run using a MJResearch Opticon ${ }^{\circledR} 2$ real-time thermal cycler. All reactions were performed in 96-well plates with each reaction well containing $12.5 \mu \mathrm{l}$ of $2 \times$ QuantiTech SYBR Green Master Mix (Qiagen), $1 \mu \mathrm{M}$ of primers, and extracted algae or copepod genomic DNA. The appropriate amount of template DNA in all assays was achieved using $5 \mu \mathrm{l}$ of the DNeasy purification eluted in $200 \mu \mathrm{l}$ of PCR grade water. Amplification conditions included an initial denaturation $\left(15 \mathrm{~min}, 95^{\circ} \mathrm{C}\right)$ followed by 35 amplification cycles $(30 \mathrm{~s}$, $95^{\circ} \mathrm{C} ; 30 \mathrm{~s}$, annealing temp; $30 \mathrm{~s}, 72^{\circ} \mathrm{C} ; 2 \mathrm{~s}, 78^{\circ} \mathrm{C}$ ). The fluorescence was determined at 72 and $78^{\circ} \mathrm{C}$ to account for primer dimer formation. Amplification cycles were followed by an extension at $72^{\circ} \mathrm{C}$ for $5 \mathrm{~min}$, and a final melting curve analysis from 65 to $95^{\circ} \mathrm{C}$. All reactions were run in triplicates.

To convert pigment concentration to algal cell number, the pigment concentration of the alga fed to copepods during these studies was determined by estimating pigment concentration from 10, 1 and $0.1 \mathrm{ml}$ of the culture and correlating it with cell counts determined by direct microscopy. Chlorophyll $a$ and cell counts were determined in triplicate (Fig. 2). For qPCR standards, algal cells were enumerated in the cultures by light microscopy using a Fuchs-Rosenthal haemocytometer and harvested by centrifugation $(7,000 \mathrm{~g})$ for $15 \mathrm{~min}$. Cell loss during harvesting was corrected for by counting and subtracting the number of cells found in the supernatant. Genomic DNA was purified from harvested cells using the Qiagen DNeasy ${ }^{\circledR}$ Blood \& Tissue kit (Qiagen, Inc.). Four-point standard curves were made by diluting the extracted DNA in nuclease-free water which amounted to $5.2 \times 10^{5}, 5.2 \times 10^{4}, 5.2 \times 10^{3}$, and $5.2 \times 10^{2}$ cells. Pigment concentration was determined in triplicates, also as described above after acetone extraction. All quantification standards were analyzed concurrently with each experimental set of copepods.

\section{Results}

Effect of DNase digestion on amplicon length and copy number

The dla-qPCR assay was first used to generate digestion profiles on naked genomic DNA from $R$. marina digested with DNase I at increasing time intervals in controlled in vitro experiments. As predicted, there was a significant negative relationship between the estimated target gene copy number and amplicon size after digestion by DNase I (Fig. 3a). Further, increased digestion time decreased the estimated copy number of all amplicons, regardless of their size. Thus, the number of copies of target genomic DNA detected by qPCR is predictably dependent on both amplicon length and time of contact with the digestion 


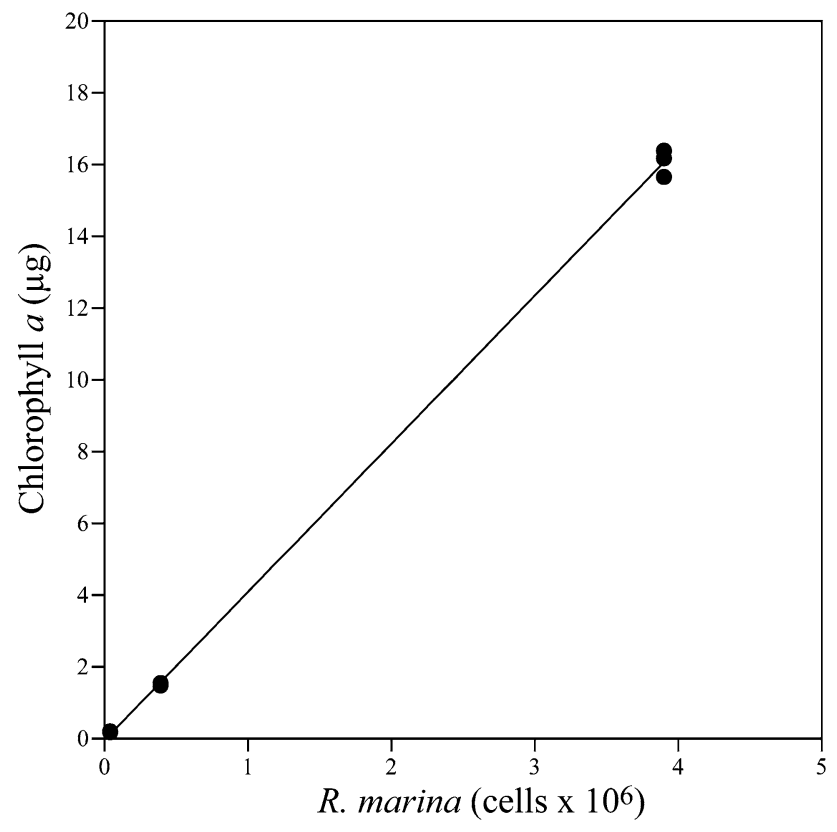

Fig. 2 Relationship between Rhodomonas marina cell number and Chlorophyll $a(\mathrm{Chl} a)$ content $(\mu \mathrm{g})$. The correlation between pigment concentration and number of prey cells was used to estimate the cell numbers in the gut of Calanus finmarchicus based on gut fluorescence

enzyme. We tested two alternative relationships between cell number estimates and amplicon size including a power function (Eq. 1) and a first order exponential decay function (Eq. 2) as previously reported by Deagle et al. (2006):

$\mathrm{CN}=a \times \mathrm{AL}^{b}$

$\mathrm{CN}=a \times \mathrm{e}^{-\mathrm{AL} \times b}$

In both equations $\mathrm{CN}$ is the number of cells and $\mathrm{AL}$ is the amplicon length. In the first case of the application of the power function 96,89 and $88 \%$ of the variance in cell number was explained by amplicon length at $30 \mathrm{~s}, 1 \mathrm{~min}$ and $2 \mathrm{~min}$, respectively. At $10 \mathrm{~min}$ most of the $20 \mathrm{ng}$ genomic DNA was digested as expected from the DNase activity specified by the manufacturer (Ambion). In the second case, the exponential decay function only explained 82,66 and $69 \%$ of the variance in cell number at $30 \mathrm{~s}, 1 \mathrm{~min}$ and 2 min, respectively. In fact, all subsequent dla-analysis yielded better fit using equation 1 than the exponential relationship (Eq. 2) used in Deagle et al. (2006).

\section{Correcting for DNA digestion in copepods by dla-qPCR}

When the dla-qPCR assay was applied to genomic DNA extracted from copepods fed $R$. marina for different time periods, we obtained digestion profiles similar to the naked $R$. marina genomic DNA treated with DNase I (Fig. 3b). The decline of prey cells detected by dla-qPCR for each amplicon length was directly related to feeding time.
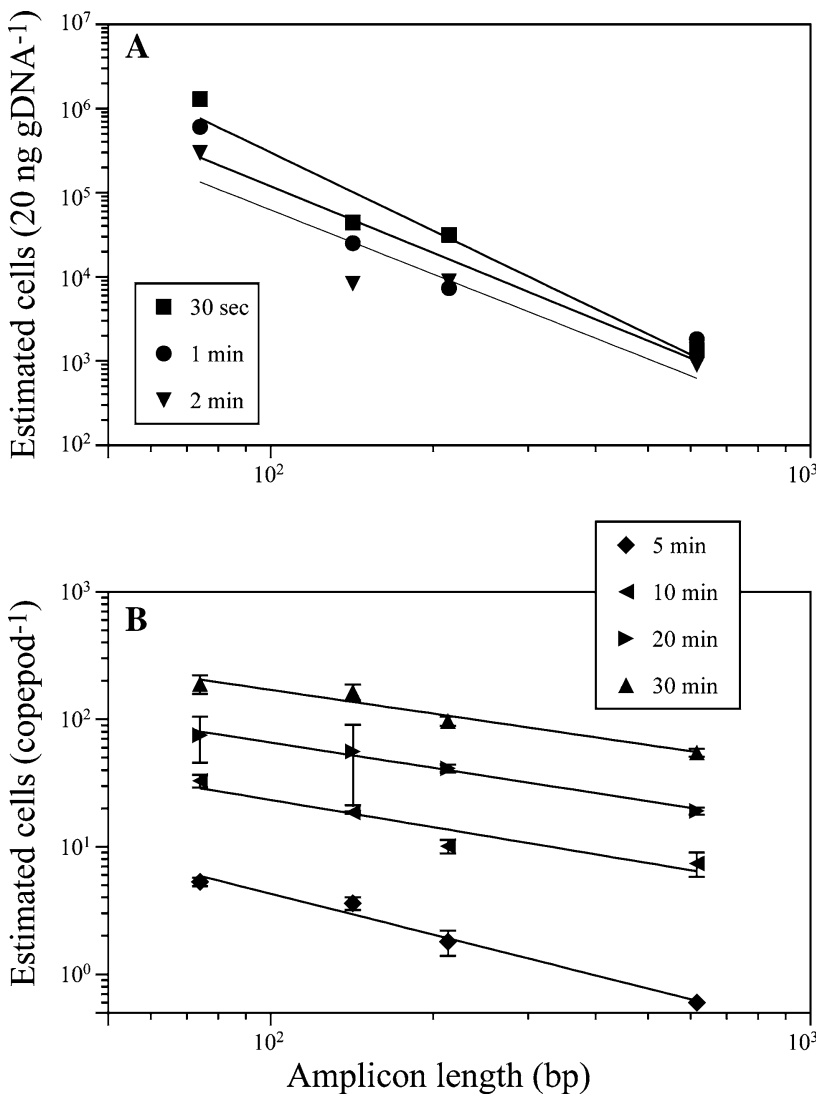

Fig. 3 a In vitro dla-qPCR on purified Rhodomonas marina genomic DNA (20 ng) incubated with 1/50 U DNase I for 0.5 (filled square), 1 (filled circle), and 2 (filled inverted triangle) min. b In vivo dla-qPCR estimates of $R$. marina cells consumed by Calanus finmarchicus. Total DNA was extracted from copepods after 5 (filled diams), 10 (filled left triangle), 20 (filled right triangle), and $30 \mathrm{~min}$ (filled triangle)

Equation 1 was fit to data explained 98, 90, 99 and 95\% of the variance in estimated cell number per copepod at 5, 10, 20 and $30 \mathrm{~min}$. These studies demonstrated that substantial but predictable digestion of prey genomic DNA occurs rapidly upon consumption by the copepod.

In order to evaluate whether the dla-qPCR could be used to correct for prey DNA digestion, additional experiments were conducted with $C$. finmarchicus fed $R$. marina for different time periods. These experiments produced copepods with a range of gut contents. Quantitative estimates of ingested prey calculated using qPCR, dla-qPCR and gut pigment analysis were compared (Table 3 ). As previously described by Nejstgaard et al. (2008), feeding rate estimates based on standard qPCR significantly underestimated copepod gut content compared to gut pigment analysis (Fig. 4). Compared to the prey cell number estimated by gut pigment analysis, estimation of $R$. marina by standard qPCR (74 bp amplicon) yielded $0.8-2.5 \%$. The dla-qPCR, on the other hand, which used the digestion profile of the prey in the gut of the copepod, estimated 
Table 3 qPCR and Chlorophyll $a$ estimates of Rhodomonas marina cell number inside the gut of Calanus finmarchicus

\begin{tabular}{lccclc}
\hline $\begin{array}{l}\text { Time } \\
(\mathrm{min})\end{array}$ & 74 & 142 & 213 & 616 & \multicolumn{1}{l}{ Chl $a$} \\
\hline 0 & $0.3 \pm 0.1$ & $1.3 \pm 0.2$ & $0.3 \pm 0.1$ & $0.3 \pm 0$ & $71 \pm 121$ \\
5 & $5.4 \pm 0.4$ & $3.6 \pm 0.4$ & $1.8 \pm 0.4$ & $0.6 \pm 0.2$ & $685 \pm 206$ \\
10 & $33 \pm 4$ & $18 \pm 0.4$ & $10 \pm 1.2$ & $7.4 \pm 1.4$ & $1364 \pm 457$ \\
20 & $75 \pm 29$ & $56 \pm 35$ & $41 \pm 2.8$ & $19 \pm 2.5$ & $6159 \pm 4539$ \\
30 & $199 \pm 37$ & $164 \pm 24$ & $92 \pm 0.3$ & $59 \pm 1$ & $11490 \pm 1152$
\end{tabular}

Cell numbers are given as mean values with standard deviation

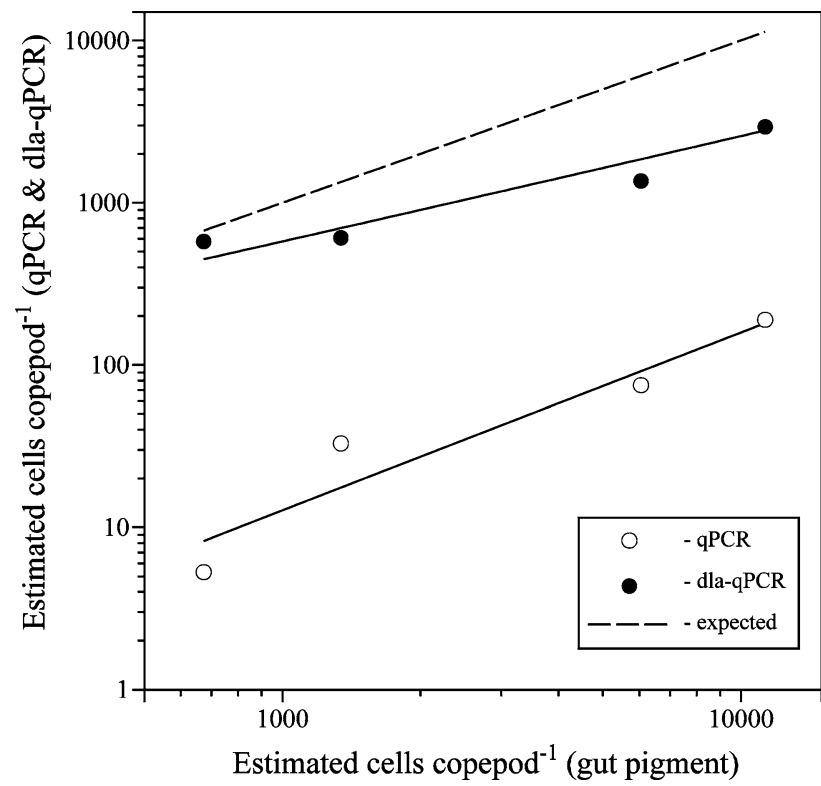

Fig. 4 Comparison of qPCR (circle) and dla-qPCR (filled circle) with gut pigment (Chlorophyll $a$ ) estimates of Rhodomonas marina cells consumed by Calanus finmarchicus. Single amplicon qPCR was based on detection of the $74 \mathrm{bp}$ amplicon. The dashed line indicates the theoretical expected 1:1 correspondence line between gut pigment and qPCR-based estimates

$22-86 \%$ (average $45 \%$ ) of $R$. marina compared to the quantification based on gut pigments (Fig. 4).

\section{Discussion}

The use of PCR-based assays for detection of prey species consumed by predatory species is becoming increasingly common (Jarman et al. 2002; Symondson 2002; Blankenship and Yayanos 2005; Galluzzi et al. 2005; Harper et al. 2005; Harwood and Obrycki 2005; Sheppard and Harwood 2005; Vestheim and Jarman 2008; Vestheim et al. 2005; Martin et al. 2006). However, direct quantification of target prey species presents a unique set of methodological challenges, and to our knowledge there are only three studies attempting such quantification in marine zooplankton; one investigating the differential ingestion and house trapping in a Urochordate appendicularian Oikopleura dioica (Troedsson et al. 2007), the second examined the gut content of the calanoid copepod Calanus finmarchicus (Nejstgaard et al. 2008), and the third investigated multicellular prey particles with Acartia tonsa nauplii stages N1 and N2 as prey for the adult female Centropages typicus (Durbin et al. 2008). In the study of Nejstgaard et al. (2008), we conducted a series of optimization experiments, including development of efficient quantitative DNA extraction and purification protocols, minimization of PCR artifacts associated with detection of prey in the environment of a predator organism, and use of appropriate quantitative calibration standards. However, although the quantification protocol was optimized, there was still a significant underestimation of gut content compared to gut pigment analysis. Although initially we hypothesized that the digestion of prey DNA would be less than that of pigments because of the greater stability of DNA compared to photosynthetic pigments, these studies suggest that DNA associated with prey organisms is rapidly digested by copepods. Also, in the study of Durbin et al. (2008) significant underestimation of target gene copy number per prey nauplii was observed in the copepod gut. Prey DNA degradation in gut and feces and the difficulty of PCR amplifying large gene fragments has previously been reported in terrestrial arthropods and mammals (Zaidi et al. 1999; Hoogendoorn and Heimpel 2001; Symondson 2002; Jarman et al. 2004; Sheppard and Harwood 2005; Deagle et al. 2006). Recently, Deagle et al. (2006) developed a model to evaluate DNA quality in fecal samples based on qPCR amplification of different sized amplicons. The dlaqPCR assay described here is based on the same principle, but is applied to obtain absolute estimates of prey consumption by copepods by correcting for DNA digestion.

Nejstgaard et al. (2008) suggest that underestimation of prey numbers ingested by copepod obtained by conventional qPCR is explained by DNA digestion. The results also suggest that it is not possible to accomplish absolute copepod gut content estimates without accounting for DNA digestion. In this study, we use the digestion profiles generated by dla-qPCR to account for DNA digestion and to correct qPCR estimates of copepod gut content. Based on digestion corrected estimates of copepod gut content, the dla-qPCR assay yielded estimates of consumed algal prey within the same order of magnitude as those determined by analysis of gut pigments (Fig. 4).

The dla-qPCR assay offers a significant improvement to non-quantitative end-point PCR and standard qPCR assays for gut content analysis that depend on the amplification and quantification of a single gene fragment. However, there are still significant challenges towards correlating for prey digestion in the field. For complete gut content 
analysis, the design of four specific primers for each prey target is often not practical and the analysis of each sample would be very expensive. It also adds uncertainty to the level of specificity for each prey species, especially when using 18S rRNA gene targets. Nevertheless, for studies where the aim to conduct quantitative estimates of specific trophic interactions, the dla-qPCR approach could provide a direct quantitative estimate. In addition, because the dlaqPCR approach yields predictable digestion profiles, it could be used in the lab to find digestion correlation factors under a given set of environmental conditions. These correlation factors could then be applied in the field where single primer $\mathrm{qPCR}$ is more practical.

Although the approach has to be further calibrated for field measurements, including knowledge about DNA gut passage time to estimate feeding rates, this study provides proof of concept for the development of PCR based approaches to estimate prey-specific in situ copepod feeding rates and provides a deeper understanding of the challenges facing future method development efforts.

Acknowledgments This work was supported by the Norwegian Research Council (NRC) project 145326/432 to C. T., NRC project $152714 / 12030$ to J. C. N. and the US National Science Foundation grants OPP-00-83381, OCE-08-25999 and the US Department of Energy Biotechnology Investigations-Ocean Margins Program (FG02-98EF 62531) to M. E. F. Special thanks to Tina Walters for invaluable technical assistance and two anonymous reviewers and Bruce Deagle for valuable comments that have significantly improved this manuscript. Anna Boyette prepared the figures.

Open Access This article is distributed under the terms of the Creative Commons Attribution Noncommercial License which permits any noncommercial use, distribution, and reproduction in any medium, provided the original author(s) and source are credited.

\section{References}

Båmstedt U, Gifford DJ, Irigoien X, Atkinson A, Roman M (2000) Feeding. In: Harris R, Wiebe P, Lenz J, Skjoldal HR, Huntley M (eds) ICES zooplankton methodology manual. Academic Press, London, pp 297-399

Båmstedt U, Nejstgaard JC, Solberg PT (1999) Utilisation of smallsized food algae by Calanus finmarchicus (Copepoda, Calanoida) and the significance of feeding history. Sarsia 84:19-38

Blankenship LE, Yayanos AA (2005) Universal primers and PCR of gut contents to study marine invertebrate diets. Mol Ecol 14:891-899. doi:10.1111/j.1365-294X.2005.02448.x

Deagle BE, Eveson JP, Jarman SN (2006) Quantification of damage in DNA recovered from highly degraded samples - a case study on DNA in faeces. Front Zool 3:11. doi:10.1186/1742-9994-3-11

Durbin EG, Casas MC, Rynearson TA, Smith DC (2008) Measurement of copepod predation on nauplii using qPCR of the cytochrome oxidase I gene. Mar Biol (Berl) 153:699-707. doi: 10.1007/s00227-007-0843-5

Galluzzi L, Penna A, Bertozzini E, Giacobbe MG, Vila M, Garces E et al (2005) Development of a qualitative PCR method for the Alexandrium spp. (Dinophyceae) detection in contaminated mussels (Mytilus galloprovincialis). Harmful Algae 4:9651130. doi:10.1016/j.hal.2005.01.004

Gruebl T, Frischer ME, Sheppard M, Neumann M, Maurer AN, Lee RF (2002) Development of an 18S rRNA gene targeted PCR based diagnostic for the blue crab parasite Hematodinium sp. Dis Aquat Organ 49:61-70. doi:10.3354/dao049061

Guillard RRL (1975) Culture of phytoplankton for feeding marine invertebrates. In: Smith WL, Chanley MH (eds) Culture of marine invertebrate animals. Plenum Press, New York, pp 29-60

Harper GL, King RA, Dodd CS, Harwood JD, Glen DM, Bruford MW et al (2005) Rapid screening of invertebrate predators for multiple prey DNA targets. Mol Ecol 14:819-827. doi: 10.1111/j.1365-294X.2005.02442.x

Harwood JD, Obrycki JJ (2005) Quantifying aphid predation rates of generalist predators in the field. Eur J Entomol 102:335-350

Hoogendoorn M, Heimpel GE (2001) PCR-based gut content analysis of insect predators: using ribosomal ITS- 1 fragments from prey to estimate predation frequency. Mol Ecol 10:2059-2067. doi: 10.1046/j.1365-294X.2001.01316.x

Jarman SN, Deagle BE, Gales NJ (2004) Group-specific polymerase chain reaction for DNA-based analysis of species diversity and identity in dietary samples. Mol Ecol 13:1313-1322. doi: 10.1111/j.1365-294X.2004.02109.x

Jarman SN, Gales NJ, Tierney M, Gill PC, Elliott NG (2002) A DNAbased method for identification of krill species and its application to analysing the diet of marine vertebrate predators. Mol Ecol 11:2679-2690. doi:10.1046/j.1365-294X.2002.01641.x

Martin DL, Ross RM, Quetin LB, Murray AE (2006) Molecular approach (PCR-DGGE) to diet analysis in young Antarctic krill Euphausia superba. Mar Ecol Prog Ser 319:155-165. doi: 10.3354/meps319155

Nejstgaard JC, Båmstedt U, Bagøien E, Solberg PT (1995) Algal constraints on copepod grazing. Growth state, toxicity, cell size, and season as regulating factors. ICES J Mar Sci 52:347-357. doi:10.1016/1054-3139(95)80050-6

Nejstgaard JC, Frischer ME, Raule CL, Gruebel R, Kohlberg KE, Verity PG (2003) Molecular detection of algal prey in copepod guts and faecal pellets. Limnol Oceanogr Methods 1:29-38

Nejstgaard JC, Frischer ME, Simonelli P, Troedsson C, Brakel M, Adiyaman F et al (2008) Quantitative PCR to estimate copepod feeding. Mar Biol (Berl) 153:565-577. doi:10.1007/s00227-0070830-x

Sheppard SK, Harwood JD (2005) Advances in molecular predatorprey ecology. Funct Ecol 19:751-762. doi:10.1111/j.1365-2435. 2005.01041.x

Symondson WOC (2002) Molecular identification of prey in predator diets. Mol Ecol 11:627-641. doi:10.1046/j.1365-294X.2002. 01471. $\mathrm{x}$

Troedsson C, Frischer ME, Nejstgaard JC, Thompson EM (2007) Molecular quantification of differential ingestion and particle trapping rates by the appendicularian Oikopleura dioica as a function of prey size and shape. Limnol Oceanogr 52:416-427

Verity PG, Smetacek V (1996) Organism life cycles, predation, and the structure of marine pelagic ecosystems. Mar Ecol Prog Ser 130:277-293. doi:10.3354/meps130277

Vestheim H, Edvardsen B, Kaartvedt S (2005) Assessing feeding of a carnivorous copepod using species specific PCR. Mar Biol (Berl) 147:381-385. doi:10.1007/s00227-005-1590-0

Vestheim H, Jarman SN (2008) Blocking primers to enhance PCR amplification of rare sequences in mixed samples-a case study on prey DNA in Antarctic krill stomachs. Front Zool 5:12. doi: 10.1186/1742-9994-5-12

Zaidi RH, Jaal Z, Hawkes NJ, Hemingway J, Symondson WOC (1999) Can multiple-copy sequences of prey DNA be detected amongst the gut contents of invertebrate predators? Mol Ecol 8:2081-2087. doi:10.1046/j.1365-294x.1999.00823.x 